\title{
Adolescent mental health: Challenges with maternal noncompliance
}

\author{
This article was published in the following Dove Press journal: \\ Neuropsychiatric Disease and Treatment \\ 27 March 2010 \\ Number of times this article has been viewed
}

\section{Vicki A Nejtek \\ Sarah Hardy \\ Scott Winter}

University of North Texas Health Science Center, Fort Worth, TX, USA
Correspondence: Vicki A Nejtek University of North Texas Health Science Center at Fort Worth, Department of Psychiatry and Behavioral Health, 3500 Camp Bowie Blvd., PCC 4.462, Fort Worth, TX 76107, USA

$\mathrm{Tel}+$ I 8177350640

Fax +I 8177350643

Email vnejtek@hsc.unt.edu
Abstract: The leading cause of suicide ideation, attempts, and completion in adolescents is persistent and unresolved parental conflict. National statistics show extremely high rates of childhood neglect and abuse are perpetrated most often by single mothers. Psychiatric disorders arising from maternal-child dysfunction are well-documented. However, resources to prevent offspring victimization are lacking. Here, we report maternal neglect of a 15 -year-old male brought to the psychiatric emergency room for suicidal ideation. An inpatient treatment plan including pharmacotherapy, family therapy and psychological testing was initiated. The patient's mother failed to attend clinic appointments or family therapy sessions. Clinician attempts to engage the mother in the treatment plan was met with verbal assaults, aggression, and threatening behavior. The patient decompensated in relation to the mother's actions. Child Protective Services were contacted and a follow-up assessment with the patient and mother is pending. Psychiatric treatment of the mother may be a necessary intervention and prevention regimen for both the adolescent and the mother. Without consistent Child Protective Services oversight, medical and psychosocial follow-up, the prognosis and quality of life for this adolescent is considered very poor. Stringent mental health law and institutional policies are needed to adequately intercede and protect adolescents with mental illness.

Keywords: adolescent, suicide, maternal treatment noncompliance, maternal neglect

Over the last few years in the United States, childhood neglect and abuse has increased from $\sim 92 \%$ to almost $94 \%$. National statistics show extremely high rates of childhood neglect (34.1\%) and abuse (26.4\%) perpetrated most often by single mothers $(25.5 \%){ }^{1}$ During the last 50 years, attachment theory research clearly shows that maternal neglect and abuse is a fundamental trigger of childhood mental illness that lasts a lifetime..$^{2-4}$ While the etiology of psychiatric disorders arising from maternal-child dysfunction is well-documented, prevention resources to halt the rise of victimization of offspring are seriously lacking. Here, we report maternal neglect and possible abuse as described in a case of treatment noncompliance for a mentally ill and suicidal adolescent inpatient.

The mother of a 15-year-old biracial male with a history of attention deficit hyperactivity disorder brought her son to the psychiatric emergency room for suicidal ideation. She reported that her son had threatened to kill himself with a gun and that she found bullets in his possession. The son denied suicidal ideation, but admitted to sadness, chronic frustration, and fear while living with his mother and two sisters. He described an altercation with his sisters that precipitated his suicidal threats which consequently led to his psychiatric emergency room admission. 
The patient was admitted to the adolescent inpatient facility and was given long-lasting methylphenidate (ie, Concerta $^{\circledR}, 36 \mathrm{mg} / \mathrm{qAM}$ reduced to $18 \mathrm{mg} / \mathrm{qAM}$ by day 3 ) and escitalopram (Lexapro; $20 \mathrm{mg} / \mathrm{qAM}$ ). Family therapy and psychological testing were also scheduled. The mother showed noncompliance as she: (1) failed to attend appointments with clinicians, and (2) neglected to attend family therapy sessions with her son during his inpatient stay. Physicians and staff made repeated attempts to consult with the mother about her son's treatment plan, and they documented that the mother responded with verbal assaults, aggression, and exhibited extreme mood lability.

On day 3, the patient's depression decreased. Learning that his mother would not attend his family therapy session with him on day 6 , his depression returned. The professional opinion of our physicians and staff was that patient decompensation was triggered chronologically by the mother's persistent neglect of her son's mental health condition evident in her noncompliance. Thus, maternal neglect was reported to Child Protective Services.

On day 7 , the patient denied any suicidal ideation, however, he admitted to anger towards his mother. He reported to hospital staff and Child Protective Services on day 8 that he feared going home with his mother. A meeting with the attending physician, patient, and his mother was scheduled on day 9. During the meeting, the mother appeared to be psychotic, delusional, and was verbally threatening. Although fearful, the patient lacked sufficient mood symptoms to warrant further hospitalization and was discharged to his mother's custody.

Upon discharge, the patient walked to the parking lot to meet his mother. Before the patient could reach the mother's car, witnesses reported that she drove off the hospital premises. Evidence shows that the mother returned home and later filed a missing person report with the police department. A Child Protective Services follow-up assessment with the patient and his mother is pending. Without consistent Child Protective Services oversight with combined medical and psychosocial follow-up, the prognosis and quality of life for this adolescent is considered very poor.

Over a half million adolescents between 15-19 years old in 2001 attempted suicide that warranted hospitalization. ${ }^{5}$ Depression alone, does not predict adolescent suicide as abusive and hostile family environments are equally predictive. ${ }^{6-8}$ Data show that the leading cause for suicide ideation, attempts, and completion in adolescents is persistent and unresolved parental conflict. ${ }^{7,8}$ In this case report, the mental instability of the mother observed by health professionals and Child Protective Services is disturbing.

Whether or not this child's mother met criteria for a mental illness arrest warrant based on her erratic behavior and the dialogue with her son's physicians is unknown. It is known, however, that offspring who suffer caregiver abuse have an $80 \%$ risk for developing multiple mental disorders, violent behaviors, and poorer global cognitive functioning. ${ }^{9-13}$ Treating maternal mental illness significantly ameliorates offspring mental disposition. ${ }^{14}$ Thus, treating the mother of this adolescent patient seems clinically relevant and necessary.

This case study reminds clinicians that adolescent mental health is critically dependent upon parental compliance and the environment in which they are raised. When parental neglect and treatment noncompliance is obvious (as in this report), mental health law and institutional health policies should be comprehensively stringent enough to adequately intercede and protect adolescents who are in need of mental health services. In this example, psychiatric treatment of the mother may have produced a more effective intervention and prevention regimen for both the adolescent and the mother.

\section{Disclosures}

Dr Winter discloses support from Janssen and Bristol Myers Squibb. Dr Winter is a current member of the Speaker's Bureau for AstraZeneca, Merck, Forest and Pfizer. Drs Nestel Hardy report no conflicts of interest in this work.

\section{References}

1. US Department of Health and Human Services. Administration on Children, Youth and Families, and Child Maltreatment. Washington, DC: US Government Printing Office; 2009.

2. Bowlby J. Maternal Care and Mental Health. Geneva, Switzerland: World Health Organization; 1952.

3. Bowlby J. Attachment and Loss. Vol. 1: Attachment. London, UK: Hogarth Press; 1969.

4. Fonagy P, Gergely G, Jurist E, Target M. Affect Regulation, Mentalization, and the Development of the Self. New York, NY: Other Press; 2002.

5. Shaffer D, Waslick B. The Many Faces of Depression in Children and Adolescents. 1st edition. Washington, DC: American Psychiatric Association; 2002.

6. Zalsman G, Brent DA, Weersing VR. Depressive disorders in childhood and adolescence: An overview: epidemiology, clinical manifestation and risk factors. Child Adolesc Psychiatr Clin N Am. 2006;15(4): 827-841, vii.

7. Brent DA. Risk factors for adolescent suicide and suicidal behavior: mental and substance abuse disorders, family environmental factors, and life stress. Suicide Life Threat Behav. 1995;25(Suppl):52-63.

8. Brent DA, Johnson BA, Perper J, et al. Personality disorder, personality traits, impulsive violence, and completed suicide in adolescents. $J \mathrm{Am}$ Acad Child Adolesc Psychiatry. 1994;33(8):1080-1086.

9. Silverman AB, Reinherz HZ, Giaconia RM. The long-term sequelae of child and adolescent abuse: A longitudinal community study. Child Abuse Negl. 1996;20(8):709-723. 
10. Teicher MD. Wounds that time won't heal: The neurobiology of child abuse. Cerebrum. 2000;2(4):50-67.

11. De Bellis M, Thomas L. Biologic findings of post-traumatic stress disorder and child maltreatment. Curr Psychiatry Rep. 2003;5(2):108-117.

12. Springer KW, Sheridan J, Kuo D, Carnes M. Long-term physical and mental health consequences of childhood physical abuse: Results from a large population-based sample of men and women. Child Abuse Negl. 2007;31(5):517-530.
13. Schore AN. Early relational trauma, disorganized attachment, and the development of a predisposition to violence. In: Solomon MF, Siegel DJ, editors. Healing Trauma: Attachment, mind, body, and brain. New York, NY: Norton; 2003.

14. Pilowsky DJ, W-ickramaratne PJ, Rush AJ, et al. Children of currently depressed mothers: a STAR*D ancillary study. J Clin Psychiatry. 2006;67(1):126-136.

\section{Publish your work in this journal}

Neuropsychiatric Disease and Treatment is an international, peerreviewed journal of clinical therapeutics and pharmacology focusing on concise rapid reporting of clinical or pre-clinical studies on a range of neuropsychiatric and neurological disorders. This journal is indexed on PubMed Central, the 'PsycINFO' database and CAS, and is the official journal of The International Neuropsychiatric Association (INA). The manuscript management system is completely online and includes a very quick and fair peer-review system, which is all easy to use. Visit http://www.dovepress.com/testimonials.php to read real quotes from published authors.

Submit your manuscript here: http://www.dovepress.com/neuropsychiatric-disease-and-treatment-journal 